\title{
Early Childhood Education Policy Development in China
}

\author{
Xin Zhou \\ East China Normal University \\ China
}

\begin{abstract}
Great progress in the field of early childhood education policy in China has been made in 2010. In the light of the National Plan for Medium and the Long-term Program for Education Reform and Development, the Chinese government has made a series of efforts aimed at promoting the development of early childhood education. The new policies include an increase in the 3-year early childhood program enrollment; the clarification of the governments' main responsibilities for the provision of early childhood education; an increase of funding for early childhood education, (especially for disadvantaged children); the strengthening of teacher capacity; and the strengthening of program quality and management amongst other changes. Each province has developed a 3-year Action Plan to implement the policy. The challenges for the implementation of the new policy are also discussed.
\end{abstract}

Key words: early childhood education, early childhood education policy, policy implementation, China

\section{The Background}

Despite the rapid development of the economy in China over recent years, the provision of early childhood education in the nation remains a major challenge. The gross enrollment for those children aged 3-6 was only $50.9 \%$ in 2009 , a figure which was not only far lower than the enrollment in developed countries, but was also lower than that seen in many developing countries in Latin America and the Caribbean (UNESCO, 2006). In fact, the number of public service programs aimed at early childhood education has been reduced dramatically over the past 20 years due to dramatic reforms to the economic system in China. For example, because of the

Correspondence concerning this article should be addressed to Xin Zhou, Professor, Department of Early Childhood Education, East China Normal University, China 3663 North Zhong Shan Road, Shanghai, 200062, China. Electronic mail may be sent to xzhou@pie.ecnu.edu.cn economic reform of public working units, many early childhood programs which used to be supported by public working units were either closed down, or integrated into other programs, some of which even having been changed to private service providers. Therefore, the private service provision has been increasing in most areas of China. From 2001 to 2007, the percentage of public early childhood services were reduced from $60 \%$ to $40 \%$, at the same time, the percentage of private early childhood service provision increased from $40 \%$ to $60 \%$ (Liu, 2010a). With great variations in terms of both motivations and resources, many private programs sought higher profits, raising their service fees, tried to adapt their programs to parents' rising demands and expectations, provided programs that were of poor quality, or inappropriate for young children. A quality monitoring system does not exist yet for private service providers in most areas. It is not surprising that in recent years, parents in many areas 
in China have not been able to find satisfactory programs for their young children, or are even unable to find available places for their children.

According to the China Education Law, education, including early childhood education, has been identified as the responsibility of government. However, in recent years, many government authorities have apparently not taken these responsibilities seriously. In particularly, for a considerable time, the investment for early childhood was very low. For example, in the past 10 years, investment in early childhood education in China only took up $1.24-1.44 \%$ of the total annual educational investment in China (Liu, 2010b). In addition, a tremendous gap has been existed for early childhood education service provision between urban and rural areas. The enrollment rate in urban areas has been as high as $99 \%$, while the enrollment in rural areas as low as $10 \%$ or lower (Zhou, 2009). Due to this low investment, early childhood teachers, particularly in rural areas have been paid poorly. Teacher qualifications, teacher-child ratio and facilities in rural areas were much worse than those of urban areas (Zhou, 2008). Therefore, the scores of children' cognitive development in the west part of China have been lower than those of the children in the east part of the country.

In March 2008, the Chinese People's Political Consultative Conference (CPPCC) proposed an important national strategy ( $\mathrm{Xu}$, Zhang, Wu, \& Zhao, 2010): Taking the development of education as a priority and building a country with strong human resources. In order to promote scientific development of education in the country, to enhance the character of the Chinese people's and celebrate the progress in the modernization of the country, it was decided to develop a national plan for medium and long-term education reform and development (2010-2020), hereinafter referred to as the Plan.

Immediately after the conclusion of the National People's Congress and the CPPCC annual sessions, President Hu Jintao and Premier Wen Jiabao both gave important instructions, calling for the drafting of the Plan. The central government provided guidelines regarding the mission and guiding principle for China's educational reform and development for the next 10 years. A leading group headed by Premier Wen Jiabao was set up in August 2008 to oversee the development of the Plan. Eleven thematic panels were formed, involving nearly 2,000 people and more than 500 scholars and experts. The central government has made it clear that education is a major issue of public concern in China and all plans should be widely discussed with the public in an effort to seek consensus. The draft of the Plan was made public for comments twice during the process of development. In the first round of public participation, over 14,000 letters were received and more than 2.1 million proposals were raised. In the second round of the public discussion, 27,855 comments were received $(\mathrm{Xu}$, Zhang, Wu, \& Zhao, 2010). In particularly, in the sector of early childhood education, early childhood teachers, researchers, teacher trainers, university professors, program directors, administration personnel, parents, etc. actively participated in the process. The quantity of the comments regarding early childhood education took the lead among all education issues a number of times on the website. Many important proposals have been raised, such as increasing government investment in early childhood education, raising the salary of early childhood teacher and their status and treatment, providing compulsory early childhood education, strengthening teacher training and early childhood education administration, providing compensatory education for disadvantaged children, etc (Feng, Wang, Xiao, Tang, \& Zhang, 2009). After carefully going through all of the proposals and opinions, the draft Plan was revised.

From January to February 2010, Premier Wen Jiabao chaired 5 meetings to listen to public opinions regarding the Plan. In April and May, 2010, Premier Wen Jiabao chaired a high level meeting of the National Science, Technology and Education Leading 
Group and the State Council executive meeting, in order to review the draft Plan. In May 27 and June 21, 2010, President $\mathrm{Hu}$ Jintao also chaired two meetings in the Political Bureau to scrutinize and subsequently adopt the Plan.

In July 2010, China announced the Outline of China's National Plan for Medium and Long-term Education Reform and Development. It presents a blueprint for achieving the modernization of education over the next 10 years. The Plan consists of a preamble, four sections and implementation measures. According to the Plan, the guiding policy for our work in education is "prioritizing development, educating people, reform and innovation, promoting equality, and improving quality“. The Plan sets a series of concrete goals, including universalizing preschool education, improving nine-years of compulsory education, raising the senior high school gross enrollment rate to $90 \%$, and increasing the higher education gross enrollment rate to $40 \%$. The Plan pledges a substantial increase in educational funding, promising to raise the proportion of national fiscal education expenditure, increasing it to $4 \%$ of total GDP by 2012 and to ensure the steady growth of this proportion in the future $(X \mathrm{u}$, Zhang, Wu, \& Zhao, 2010).

\section{The New Policies for Early Childhood Education in China}

The year of 2010 is thought to be the most important year and to many, even represents a milestone year in the history of early childhood education in China, since several very important events have happened in a short period of time, which it is believed will have a major influence on early childhood education in the nation over the next decade.

\section{Early childhood education goals specified in the Plan}

The Plan proposes the goal of better access to early childhood programs nationwide by the year 2020. At the same time, it sets forth that the main tasks and important strategies for the development of early childhood education in the next 10 years.

Comprising three articles, Chapter 3 in the Plan is devoted to early childhood education. Article 5 raises the goal of better access to early childhood programs for children aged 3-6 over the next decade. It indicates that early childhood education is critical for young children's health, habit formation and intellectual development. Early childhood programs need to acknowledge children's developmental nature, use scientific teaching methods and ensure that children develop in a healthy and happy manner. As Table 1 indicates, up to the year 2020, all children in China will have full access to one year of early childhood education; most children in China should have full access to two years of early childhood education, and three years of early childhood education should be accessible for the children in developed areas. Attention should be also paid to the education of children from birth to three.

Table 1

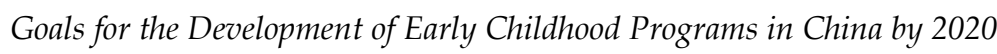

\begin{tabular}{lcccc}
\hline \multicolumn{1}{c}{ Indicators } & Unit & 2009 & 2015 & 2020 \\
\hline Preschool enrollment in ECE programs & 10000 & 2658 & 3400 & 4000 \\
Gross preschool enrollment in one-year program & $\%$ & 74.0 & 85.0 & 95.0 \\
Gross preschool enrollment in two-year program & $\%$ & 65.0 & 70.0 & 80.0 \\
Gross preschool enrollment in three-year program & $\%$ & 50.9 & 60.0 & 70.0 \\
\hline
\end{tabular}


Article 6 clarifies the government's responsibility for the provision of early education services. It indicates that governments need to include early education services into their city or town development plans. The mechanism for the early education program provision is identified as: the government takes the main leadership role while social participation is encouraged. Both public and private funding could be used in early child education provision. The government needs to increase the level of investment into early education services while different sectors of society may share the costs. Financial support will be provided for low-income families. Program standards and licensing requirements need to be established. Teacher qualification and the overall quality of the teaching staff could be enhanced by professional development. Teachers' salaries, status and treatment needs to be ensured by law. The educational administration at all levels needs to provide overall guidance and management for early education services, with each sector taking their relevant responsibilities.

Article 7 calls for the strengthening of early education service provision in rural areas. It proposes that efforts should be made in increasing the access to early education program in rural areas, especially for those children whose parents have left home to take up urban jobs. A variety of strategies may be used to expand the services, such as renovation of old buildings, expansion of original buildings, or building new schools, etc.

\section{The State Council documentation for early childhood education}

A few months after the release of the Plan, in order to better implement the Plan, in November 2010, the China State Council issued Document 41\#, entitled Issues Regarding Current Development of Early Childhood Education. It is an important document for the development of early education services in China. The document, for the first time in Chinese history, treats early childhood education development as an important measure for protecting and improving people's lives. The document has created a complete system design for early childhood education and developed a series of important strategies. The document finally requires every county in the nation to develop a three-year initiative plan for the development of early childhood services. Ten top issues in the development of early childhood education have been identified in the document:

(1) The development of early childhood education should assume a more important position in the nation. Early childhood education is still the weakest element in our education system. In order to build a public early childhood education service system, to provide convenient, flexible, diverse programs for children and parents, the government should take the lead and involve different social sector stakeholders, including private investment. The government, at all levels in the nation should situate early childhood education development as an important part of the government agenda.

(2) Expanding early childhood education resources in a variety of ways. More government funding should be used to strengthen the public early childhood education service provision. The government may also use a variety of strategies to support private programs. Early childhood service programs should be set up based on the size of the local residence, including the children of migrant workers. Beginning from 2010, the central government will provide special funding to support early childhood education in rural areas in the west part of China.

(3) Strengthening the building of teacher capacity. Each province needs to define an appropriate teacher-child ratio and ensure the program hires enough qualified teachers to meet the requirement. The government will issue early childhood teacher professional standards soon 
and the minimum teacher qualification needs to be clarified. The law should protect teachers' rights and treatment. The pre-service teacher training system needs to be improved, including services and courses provided by universities, colleges and middle level training schools. Innovative in-service teacher training systems need to be explored in order to meet teachers' diverse needs for learning and development. 10,000 early childhood directors and teachers will be trained in 3 years nationwide. Each province needs to provide one round of training for all the program directors and teachers within 5 years.

(4) Increasing the level of investment for early childhood education services in a variety of ways. The funding for early childhood education should take up an appropriate proportion in the whole education budget, with an obvious increase over the next 3 years. Central government will provide special funding for the west and undeveloped areas, for the education of minority children and education for bilingual language education.

(5) Strengthening the management for the early childhood education program application and licensing system. Each province should develop program standards based on central government regulations and diverse social needs. Local governments need to provide guidance, management and monitoring.

(6) Strengthening the security of early childhood programs. Children's safety needs to be protected and secured.

(7) Regulating and managing the fees for early childhood programs. The central government will issue a regulation for early childhood program fee management in 2011.

(8) Applying scientific care and education to improve children's healthy development. The central government will issue early childhood learning and development guidelines shortly.
Early education should follow children's developmental characteristics, education for all children as well as pay attention to individual child. Play should be treated as the main activity in the program, combining care and education, since children learn through a variety of activities and in an enriched learning environment. An effective early childhood program quality monitoring system should be set up.

(9) Improving the working mechanism and strengthening organizational leadership. Local government should strengthen the coordination of different educational sectors, creating a more integrated system for promoting the development of early childhood education.

(10)Developing and implementing early childhood education through a 3-year Action Plan. Local government collects basic information and identifies problems in early childhood education, and then develops a series of scientific predictions for preschool children's enrollment needs in the near future, and then identifies gaps between the current programs and the needs based on local economic developments, population distribution and its future development trends. The plan should clarify specific developmental goals for different time points and secure the financial resources that are needed. The provincial government is required to submitsuch an action plan to the State Council before the end of March 2011. The Ministry of Education will monitor the implementation of the 3-year Action Plan.

\section{Central Government's Promotion of Early Childhood Education}

Since the issue of the Plan, China government has 
held several important meetings to discuss and push the implementation of the working goals for early childhood education for the coming three years. On November 2, 2010, premier Wen Jiabao visited 2 early childhood programs in Beijing and had a group interview with the teachers and parents. Premier Wen emphasized that the government would invest more money and provide greater support for early childhood education. On November 3, 2010, premier Wen Jiabao organized a steering committee meeting, discussed and released a series of strategies for developing early childhood education across the nation. On December 1, 2010, a national early childhood education teleconference was held in the State Department meeting hall. The purpose of the meeting was to promote the implementation of the goals set up in Document 41\#. Educational administration at different levels of educational committees in all the provinces, cities and counties participated in the meeting. The China State Council Committee member Ms. Yandong Liu attended the meeting and gave a presentation.

These meetings are regarded as the highest ranking in the country. This clearly confirmed that after a long period of time, the Chinese government has finally recognized the importance of early childhood education, and it also reflected the nation's determination and confidence in developing early childhood education. In 2010, the central government already started the promotion of early childhood education programs in rural areas. The government invested 500 million RMB in 10 provinces in the west part of China to support 61 counties in building ECE programs in rural areas. In 2011, the central government will increase levels of investment for this project.

As specified the Plan, the central government will start early childhood education experimentation in sites chosen from 15 provinces. The purpose of this experimentation was to explore ways to build a better system for running public ECE programs, to find appropriate mechanisms for ECE investment, management, human resources and to find solutions to problems in these areas. Another aim was also to increase the power for innovation in the reform and to find resolutions in the realization of governmental responsibility; to build an early childhood public education service system; and finally to promote scientific development of early childhood education on a nationwide basis (Zheng, 2010).

\section{Provincial Policy Strategies for the New ECE Policy}

Early childhood education in China has been an important focus for provincial government since the release of the new policy. Provincial governments have taken immediate action to implement the Plan and the new policy by the way of coordination and cross-sectoral cooperation. Many provincial governors have taken the lead in the research and have organized relevant meetings to develop local policy and action strategies.

Each county in the country was required to develop a 3-year action plan, which includes 4 components: 1 ) Current conditions, problems and challenges in the provision of early childhood education; 2) Goals and tasks for the development of early childhood education over the next 3 years, including overall, annual and geographic area objectives; 3) Main strategies, including the enhancement of public ECE enrollment, supporting private early childhood programs, securing of financial support for ECE, securing teacher training and better conditions for teachers, clarification of the government responsibility and completing a management system, strategies for enhancing program quality, etc.; 4) Important ECE projects that may be undertaken over the next 3 years, including the name of the projects, goals, strategies and funding for the project, etc. The provincial government will collect plans from the city and county level and then develop a provincial 3-year plan based on these submissions. 
Up until early May 2011, more than 10 provinces have released their 3-year action plans on their website, some of which were still drafts. Based on the analysis of this information, it seems that implementation efforts at the provincial level include all issues relating to the 10 issues specified in

Table 2

Goals Specified in Selected Provincial 3-year Action Plans

\begin{tabular}{|c|c|c|}
\hline Province & Enrollment & Program \\
\hline $\begin{array}{l}\text { Shan- } \\
\text { dong }\end{array}$ & $\begin{array}{l}\text { By } 2015,3 \text {-year ECE program enrollment } \\
75 \% \text {, developed area }>85 \% .\end{array}$ & $\begin{array}{l}\text { By } 2015 \text {, over } 70 \% \text { ECE programs will be public run } \\
\text { programs, and all will meet the provincial quality } \\
\text { standards. }\end{array}$ \\
\hline Fujian & $\begin{array}{l}\text { By 2015, 3-year ECE program enrollment } \\
93 \% \text {. }\end{array}$ & $\begin{array}{l}\text { One program is set up for a population of } 10,000 \text { in } \\
\text { towns, and } 3,000-6,000 \text { in rural areas. }\end{array}$ \\
\hline Guizhou & $\begin{array}{l}\text { By } 2015,3 \text {-year ECE program enrollment } \\
60 \% .\end{array}$ & $\begin{array}{l}\text { By 2020, provincial finance will support 1,000 new ECE } \\
\text { programs, each town or city neighborhood will have at } \\
\text { least one public ECE program. }\end{array}$ \\
\hline Hainan & $\begin{array}{l}\text { By } 2013 \text {, one year ECE program } \\
\text { enrollment }>80 \% \text {; 3-year ECE program } \\
\text { enrollment }>55 \% \text {. }\end{array}$ & $\begin{array}{l}\text { By 2013, } 30 \text { new public ECE programs will be built, } 100 \\
\text { town programs renovated or enlarged. Over } 75 \% \text { of the } \\
\text { towns will have public central ECE programs. Over } 20 \% \\
\text { of the programs will meets provincial or city quality } \\
\text { standards. }\end{array}$ \\
\hline Hebei & $\begin{array}{l}\text { By 2015, 3-year ECE program enrollment } \\
70 \% .\end{array}$ & $\begin{array}{l}\text { By 2012, 1,000 ECE programs will be either renovated or } \\
\text { newly established. }\end{array}$ \\
\hline $\begin{array}{l}\text { Heilong- } \\
\text { jiang }\end{array}$ & $\begin{array}{l}\text { By 2015,3-year ECE program enrollment } \\
65 \% .\end{array}$ & $\begin{array}{l}\text { By } 2015 \text {, public programs will comprise takes over } 40 \% \text {, } \\
\text { and } 80 \% \text { of programs will reach basic program } \\
\text { standards. }\end{array}$ \\
\hline Shanxi & $\begin{array}{l}\text { By 2013, 2-year ECE program enrollment } \\
85 \% \text {; 3-year enrollment } 75 \% \text {. One year of } \\
\text { free ECE education starts from } 2011 .\end{array}$ & $\begin{array}{l}\text { By 2013, 1,000 public town ECE programs will be } \\
\text { established; each county will have at least one standard } \\
\text { program. An ECE network will be built with city, town } \\
\text { and village service systems. }\end{array}$ \\
\hline Anhui & $\begin{array}{l}\text { By 2013, 3-year ECE program enrollment } \\
60 \% .\end{array}$ & $\begin{array}{l}\text { By 2012, } 973 \text { new public ECE programs will be } \\
\text { established, and } 955 \text { public ECE programs will be } \\
\text { renovated or enlarged. }\end{array}$ \\
\hline Sichuan & $\begin{array}{l}\text { By 2015, 3-year ECE program enrollment } \\
70 \% .\end{array}$ & $\begin{array}{l}\text { By 2013, } 1200 \text { new public ECE programs, and } 500 \text { private } \\
\text { program will be established. }\end{array}$ \\
\hline $\begin{array}{l}\text { Guang- } \\
\text { dong }\end{array}$ & $\begin{array}{l}\text { By } 2015 \text {, compulsory } 3-\text { year ECE } \\
\text { program for all children. }\end{array}$ & \\
\hline
\end{tabular}


here for 3-year enrollment by 2015 is higher than the national goal specified in the Plan. By 2015, Guangdong province will provide compulsory ECE education for all children. Shanxi province will start one year of free education for children aged 5-6 from September 2011. Nanjing will start free education plan for all children aged 3-6 in the city, including for the children of migrant workers. All 170,000 children will receive $2000 \mathrm{RMB}$ for each of the 3 years of the ECE program.

\section{Increasing investment for early childhood education}

In the 3-year Action Plan, all provinces proposed several strategies for meeting this requirement:

(1) Increasing the levels of investment for early childhood education in a variety of ways.

(2) Including early childhood education funding into the educational budget and ensuring that early childhood funding is secured at an appropriate proportion in the whole education budget, with the goal of increasing it over the next 3 years.

(3) The government, at all levels, is required by the State to provide special funding for the education for disadvantaged children, including children from low income families, orphans and children with special needs, etc.

(4) Developed areas may consider free education for children or children from low-income families.

\section{Teacher capacity building}

In the 3-year Action Plan, the strategies for building teacher capacity may take a number of forms, such as

(1) Establishing a regular ECE program director and teacher in-service training system. For example, Sichuan province will provide teacher in-service training for all the teachers in the ECE program in the province in 3 years; Shanxi province will complete the in-service training

Table 3

Investment planned in some of the 3-year of Action Plan

\begin{tabular}{|c|c|c|}
\hline Province & Time & Investment Plan \\
\hline Guizhou & 2011-2020 & $\begin{array}{l}\text { The government will provide } 500 \text { thousand RMB for the town or street } \\
\text { communities which currently lack a public ECE program. }\end{array}$ \\
\hline Hainan & By 2013 & $\begin{array}{l}\text { The government has specified that local financial budget for early childhood } \\
\text { education should reach } 2 \% \text { in } 2013 \text {. }\end{array}$ \\
\hline Shanxi & 2011-2013 & $\begin{array}{l}\text { The government has planned to provide } 200 \text { million annually for early } \\
\text { childhood education over the next } 3 \text { years, in supporting one year of free early } \\
\text { childhood program and the establishment of new programs. In addition, the } \\
\text { provincial government will provide cash rewards for local government, namely, } \\
500 \text { thousand RMB for the establishment of one new town central program, and } \\
300 \text { thousand for the renovation of one town central program. }\end{array}$ \\
\hline Sichuan & 2011-2013 & $\begin{array}{l}\text { The government will provide an estimated } 2,400 \text { million investment for early } \\
\text { childhood education over the next } 3 \text { years. }\end{array}$ \\
\hline Beijing & 2011-2015 & $\begin{array}{l}\text { The government has planned to invest } 5,000 \text { million RMB to build or renovate } \\
600 \text { ECE centers over the next } 5 \text { years in order to increase the proportion of } \\
\text { public programs to }>70 \% \text {; the funding transferred to the program for each child } \\
\text { will increase from } 200 \mathrm{RMB} \text { to } 1200 \mathrm{RMB} \text { annually. }\end{array}$ \\
\hline
\end{tabular}


for 15,000 teachers and 1,800 program directors in 3 years.

(2) Strengthening teacher pre-service training programs. For example, Guizhou government is attempting to explore the possibility of opening a 5-year school program for junior high school students; Hebei has plans to support the development of 3-5 early childhood teacher training schools. Fujian has identified 2 colleges as the main provincial bases for ECE teacher training and will also encourage universities to increase their capacity for teacher training.

(3) Widening the resource for teacher recruitment. For example, Guizhou has planned to recruit teachers via multiple routes; to provide better salaries or conditions for new graduates who are willing to work in rural area programs, etc. Anhui province will use open recruitment to recruit 20,000 teachers and to re-train 5,000 primary teachers to work in ECE programs.

(4) Strengthening program management for teacher qualification. Teachers, directors and other ECE personnel should meet the requirements for the minimum training standards.

(5) Establishing better teacher salaries, conditions and social security systems. In this regard, no detailed plan has been made. One province proposes that the mechanism for teacher incentives and discipline needs to be established.

\section{Challenges for the Implementation of the New Policy}

Although great progress has been made in the policy development in early childhood education in China, the actual progress in the development of early childhood education will not be realized unless the policy is implemented successfully. China is a country with diverse geographic conditions, diverse cultures, diverse economic and social development levels and diverse early childhood education conditions as well. The implementation of any central government policies may face obstacles and challenges. The possible immediate challenges for the implementation of the new early childhood education policy are as follows:

State Document 41\# identified that the government should take the main responsibility for the provision of early childhood education, but, in reality, how do we define the main areas of responsibility? How does the government realize it's main responsibility? What can be done if the government does not take up these responsibilities? In previous years, because of a variety of reasons, the government at various levels has not taken sufficient responsibility for early childhood education. For example, the government did not have enough personnel in the key area of ECE administration, and the investment for public early childhood education has been very low and has even decreased (Liu, 2010). How then can the government take proper responsibility and how can it be monitored under the new policy?

In the framework of the 3-year Action Plan, the enrollment rates for the 3-years of the ECE program in all the provinces will be increased in a few years; this means that a great many new ECE programs will start running and this will require the obvious provision of a large number of qualified teachers in a short period of time. This is really the greatest challenge for all provinces. Current capacity for pre-service teacher training is too small to meet such requirements in all provinces.

The third challenge that may closely relate to the fast development of early childhood education in the coming years is the questionsas to how we ensure that the pursuit of increasing the quantity of early childhood program is not at the expense of the quality of such programs. How can the quality of the program be secured in the context of such rapid development? Although all provinces have proposed 
some measures to strengthen the quality of ECE programs, it seems that no concrete strategies have been undertaken in their plans.

Another huge challenge is the change in early childhood education in rural areas. Overall, the ratio for early childhood education provision in China is low, especially in the west part of China and in other rural areas. How we make changes in early childhood education in those areas is key to the success of the policy implementation across the whole nation. It is fortunate that the central government will provide special funding for those areas. However, whether the government in those areas really uses the funding for early childhood education, or uses it in the most appropriate ways in early childhood education still remains to be seen. In Chinese culture, investment in education is often thought of in terms of investment in hardware, such as the investment for new buildings or facilities and less attention is paid to the software, such as teacher qualification, teacher training, teacherchild interaction, and the most important part, the quality of the education program itself. The central and provincial government will all provide special funding for the education of disadvantaged children. This is a new policy in China and how to implement such a policy is itself a challenge for everybody involved.

In conclusion, great progress in early childhood education policy in China will bring enormous benefits for millions of children and parents. It will also bring hope, and opportunities as well as great challenges for early childhood education professionals. China still has a long way to go in meeting the educational needs of our young children.

\section{References}

Accelerating the development of early childhood education, solve early childhood program access problem. (2011, February 23). China Education Newspaper. Retrieved May 22, 2010, from http://news.cntv.cn/20110120/ 104149.shtml

China Government website. (2010, November 3). Study and deploy policy strategies for the development of early childhood education. Retrieved May 2, 2011, from http://www. gov.cn/ldhd/2010-11/03/content_1737322.htm

China National Institute for Educational Research [CNIER]. (2010). A study on the strategies for the development of early childhood education in China (pp. 18-19). Beijing: Educational Science Press.

China State Council. (2010). The outline of China's national plan for medium and long-term program for education reform and development (2010-2020). Retrieved May 25, 2011, from http:// www.gov.cn/jrzg/2010-

07/29/content_1667143. htm

Feng, X. X., Wang, L. Y., Xiao, S. J., Tang, M., \& Zhang, H. R. (2009). Focusing on the state medium and long term program on education reform and development about preschool education, an analysis on the comments to early childhood education. Early Childhood Education Research Journal, 6, 3-9.

Guizhou government News Release Office. (2011, March 31). Regarding the implementation of promotion of early childhood education development. In Guizhou Daily. Retrieved May 2, 2011,http://gzrb.gog.com.cn/system/2011/03/3 0/011050047.shtml

Hainan Government. (2010, December). 3-year action plan for early childhood education reform and development. Retrieved May 2, 2011, from http:/ /www.hainan.gov.cn/data/yjzj/2010/12/ 132

Hebei Government. (2011, December 28). Opinions regarding the promotion of early childhood education (No. 1). Retrieved May 2, 2011, from http://www.hee.cn/col/1224901513187/1298429 227868.html

Heilongjiang Government. (2011, March 29). Opinions regarding the promotion of early childhood education reform and development (No. 20). 
Retrieved May 2, 2011, from http://www. hlje.net/e/action/ShowInfo.php?classid=215\&id $=56695$

Jiangsu Government Office. (2011, November). Regarding the promotion of early childhood education reform and development (No. 136). Retrieved May 2, 2011, from http://www. jiangsu.gov.cn/tmzf/szfxxgk/szfxxgkml/szfbgt wj/4371/201011/t20101123_536599.html

Liu, Z. L. (2010a). Developing early childhood education is the obligation of the government in all levels, the confirm of the government's obligation in the national medium and long term program on education reform and development.

Early Childhood Education Research, 11, 12-16.

Liu, Z. L. (2010b). The realization of full access to early childhood program should combine with the enhancing of the quality, the meaning and strategies in the realization of full access to early childhood education in the plan. Early Childhood Education Research Journal, 10, 18-22.

Ministry of Education. (2011). First news release in 2011: An introduction for promotion of early childhood education in 6 months since China National Educational Working Conference. Retrieved May 2, 2011, from http://www. moe.edu.cn/publicfiles/business/htmlfiles/moe /s5156/201102/115162.html

Qinghai Government. (2010, May). Regarding promotion of early childhood education development. Retrieved May 2, 2011, from http:/ /www.law-

star.com/cacnew/201003/345 054546.htm

Shanxi Government. (2011, February). Office of Shaanxi Provincial People's Government on Printing Pre-primary three-year action plan (2011-2013) notice. Retrieved May 2, 2011, from http:/ / www.shaanxi.gov.cn/0/104/8181.htm

The State Council Document. (2010). Issues regarding current development of early childhood education. Retrieved May 25, 2011, from http://www. gov.cn/zwgk/2010-11/24/content_1752377.htm
UNESCO. (2006). EFA global monitoring 2007. UNESCO Publishing. Retrieved May 2, 2011, from http:/ / unesdoc.unesco.org/images/0014/ 001477/147794e.pdf

Wang, P. (2010). China's new national education plan aims to build a country with rich human resources. Retrieved May 22, 2010, from http://www.Xinhua.net

Zhen, F. Z. (2010, December 10). Find strategy to promote early childhood education, interpretation for the state document. Retrieved May 2, 2011, from http://www. gov.cn/ zxft/ft211/

Zhou, X. (2008, July). Knowledge-based economy and early childhood education equality in China context. Paper presented at the annual conference of the Pacific Early Childhood Education Research Association, Thailand.

Zhou, X. (December, 2009). Observation from developing early learning and development guideline. Paper presented at the ECE Policy Review Seminar, Singapore.

Xu, Y. Y., Zhang, Z. T., Wu, J., \& Zhao, C. (2010, July 31). A blueprint for educational modernization. Retrieved May 25, 2011, from http://www. moe.edu.cn/publicfiles/business/htmlfiles/mo e/moe_2862/201010/109029.html 